


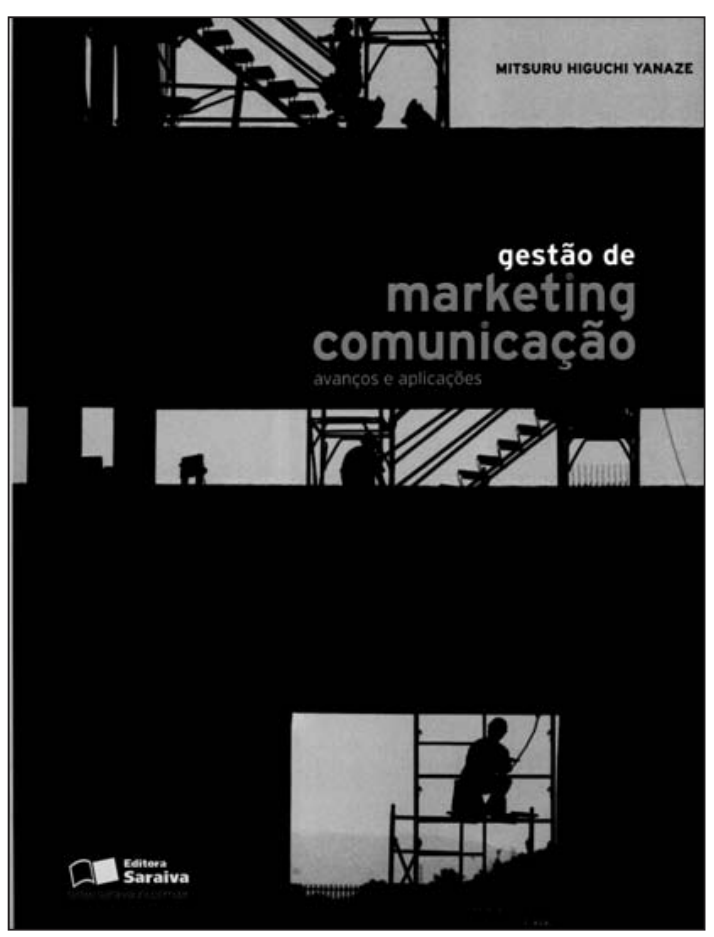

Mitsuru Higuchi Yanaze

Gestão de Marketing

e Comunicação:

avanços \& aplicações

São Paulo:

Saraiva, 2007.

554 páginas

Claudio Cardoso

- Pós-Doutor pela George Washington University

- Doutor e Mestre em Comunicação pela

Universidade Federal da Bahia (UFBA)

- Professor do Núcleo de pós-graduação da Escola de Administração da UFBA

- ccardoso@ufba.br 


\section{Marketing levado a sério}

$\mathrm{F}$ inalmente uma obra que trata o Marketing de forma articulada, ampla, profunda e precisa. A obra do professor Yanaze faz jus a esse pequeno conjunto de adjetivos. Características que ganham maior relevância quando se tem em perspectiva a enorme carência de obras de qualidade sobre o tema do Marketing em nosso país.

Parte significativa da comunidade empresarial brasileira, em especial aquela formada pelos empreendedores mais qualificados intelectualmente, e praticamente todo o conjunto de professores dos programas nacionais de pós-graduação em Comunicação Organizacional, ou temas afins, se ressentem de referências bibliográficas sustentadas por sistemas teóricos consistentes, em vez do tradicional acervo de receituários destinados a se tornarem best sellers.

O novo livro oferece ao leitor uma visão completa das diversas dimensões e atividades do Marketing, partindo de uma conceituação que o coloca na esfera de um sistema de gestão das organizações a partir da decisão estratégica em adotá-lo desta forma, como um princípio empresarial orientador, que busca "alcançar e manter o equilíbrio entre o potencial da empresa e o potencial do mercado".

Desse modo, nem conjunto de teorias, nem ferramenta para atender às demandas do mercado. A importância do Marketing torna-se decisiva para as organizações nos dias de hoje. Sobretudo quando acompanhamos o autor em sua análise das visões mais tradicionais sobre o Marketing preconizadas até o momento, que se limitam à relação da empresa com o seu mercado, digamos, mais direto e aparente.

O professor Yanaze toma uma direção praticamente oposta para compreendê-lo: o Marketing deve ser um "princípio de trabalho" capaz de orientar as ações de uma organização rumo à otimização da entrega de valor para todos aqueles atingidos ou envolvidos em suas atividades, sejam sócios, autoridades, governos, formadores de opinião, entidades nacionais ou estrangeiras ou ações do terceiro setor.

Além dessa conceituação articulada, que transparece toda a experiência do autor como "profissional de campo", a obra generosamente oferece ao leitor teorias formuladas pelo próprio autor, em destaque aquela dos três "puts" (input, throughput e output), que versam sobre a questão do relacionamento entre empresa e mercado, e da empresa consigo mesma, internamente. 
Adicionalmente, o leitor vai encontrar, ainda na parte inicial do livro, o detalhamento de modelos de análise clássicos, porém ainda muito efetivos, tais como o BCG ou o SWOT.

Contudo, não se trata de obra de autor solitário. Um grupo de 21 co-autores experientes, tanto em práticas como em teorias, elaborou vários dos 30 capítulos agrupados em dez partes, cada uma delas dedicada a temas cruciais, tais como os conceitos fundamentais e os objetivos, o planejamento, estudos de mercado, a distribuição de produtos, e muitos outros elementos de alta relevância para a compreensão e as práticas do Marketing.

Gestão de Marketing: avanços \& aplicações reduz a solidão dos professores em sala de aula, ávidos por obras articuladas e completas sobre o assunto, capazes de sustentar discursos teoricamente consistentes e reflexões ilustradas sobre as várias questões que cercam o assunto. Também, a obra serve de companhia para empresários e executivos, carentes de boas análises sobre os desafios por eles enfrentados e muitas vezes sem qualquer preparo para compreender o alcance estratégico e a capacidade que o Marketing tem de gerar resultados. 